\title{
Axiological Interpretation in the Thought of Max Weber: To Rediscover an Important Hermeneutical Concept
}

\author{
NICOLAE RÂMBU \\ Faculty of Philosophy, University “Alexandru Ioan Cuza” Iaşi, B-dul Carol I, 11, lași, 700506 Romania \\ Email: nikolausrambu@yahoo.de
}

\begin{abstract}
In this article, we defend the thesis according to which the axiological interpretation (Wertinterpretation) of Max Weber might play an important role. This is important not only in the field of social sciences methodology, but also within philosophical hermeneutics, where no one has given it any special attention so far. Indeed, no hermeneutics history has noted the concept of axiological interpretation. Starting from this concept and from the reality it describes, because without using the expression itself, the phenomenon of interpreting values is a constant presence in the history of any civilisation, the author of this article pleads for establishing a hermeneutics of values, a subject only sketched so far in literature.
\end{abstract}

Keywords: hermeneutics of values, axiological interests, reference to values

\section{IDEAL TYPE AS A HERMENEUTIC INSTRUMENT}

The concept of axiological interpretation has not been assimilated yet by the philosophical hermeneutics, meaning that it does not record it in any specialized dictionary and in any history of hermeneutics. This concept does not appear in Hans Georg Gadamer's monumental work Truth and Method, in which Max Weber is mentioned several times, but is related to such concepts as reference to values or ideal type (Gadamer 2004: 508-509). Axiological experience would have been as important as 'the experiences of philosophy, of art, and of history itself' (Gadamer 2004: $\mathrm{XXI}$ ) in determining the concept of hermeneutical experience, which represents one of the fundamental issues Gadamer raises in his book Truth and Method.

This shortage is explained by the fact that what Max Weber named Wertinterpretation (Weber 1922: 277) is not only a hermeneutical concept, but it also belongs, above all, to the methodology of culture sciences. Our thesis, which we defend in this essay, is that axiological interpretation is a concept that has to be recovered for philosophical hermeneutics, taking into consideration that Max Weber himself was a sociologist greatly influenced by philosophy. His conception of value interpretation was developed under the influence of Friedrich Nietzsche, Heinrich Rickert and Wilhelm Dilthey.

If 'our values are introduced into things by the movement that interprets' (Nietzsche 1999: 389), as Friedrich Nietzsche states in The Will to Power, it means that they can be brought to light 
also by a certain type of interpretation. This is, basically, the axiological interpretation of Max Weber, a disciple of Friedrich Nietzsche in the field of philosophy of values. Through his work, value became a first-class philosophical issue at the end of the 19th century and the beginning of the 20th century. It could no longer be ignored by researchers in the field of human sciences (Geisteswissenschaften), who would also make value a major theme of debate in that period. If in philosophy value quickly made a spectacular career and a multitude of philosophies of values had been developed, in social and political sciences, this term has been regarded with reservation, due to the impossibility of clearly defining such a concept. In this respect, Max Weber specified, 'The neglect of clear-cut concept-construction in practical discussions of practical, economic and social policy can, however, become particularly dangerous. It is really unbelievable to an outsider what confusion has been fostered, for instance, by the use of the term "value" - that unfortunate child of misery of our science, which can be given an unambiguous meaning only as an ideal type' (Weber 1949: 107).

Further, we are going to present briefly Max Weber's ideal type concept so that we may then point out its hermeneutic character, which is less approached in literature. The ideal type represented a problematic concept for a long time. On the one hand, it is a theoretical construction destined to confer on the culture sciences a rational ground and, on the other hand, it is a product of the researcher's imagination. Max Weber states that the ideal type is an Idealbild (Weber 1985: 191), which has a strictly epistemological function, not one of reflecting reality. Although it is only an abstract construction or a Gedankenbild (Weber 1985: 191), the ideal type also encloses certain aspects of reality that it refers to, but these are reorganized in a system without contradictions.

A researcher of Max Weber's work remarked, 'From the moment man has looked for meaning and order in the world, these where rather found in the motion of the stars than in his own world' (Steinvorth 1994: 445). The ideal type is nothing else than a means of attributing rationality, meaning and cultural significance to chaotic phenomena in humankind history. All that is called 'capitalism,' 'city economics', 'dark ages', 'late antiquity', as well as other similar conceptual constructions, represent ideal types, Max Weber states. Such abstract construction is nowhere to be found in the empirical reality. It has an utopian character. The ideal type is achieved by putting the empirical chaos in order. Applied with caution, the ideal type represents the only appropriate means of clarifying and rational ordering of the historic universe. Nevertheless, the error of seeing something else in an Idealtypus, namely a representation of reality, occurs oftentimes. In order to remove the ambiguity of the ideal type term, Max Weber explains that we have to distinguish between the ideal in the sense of a desirable result of becoming and the ideal type that is ideal, but in a strictly logical sense. This second meaning is essential for its use as an efficient tool of cognition in the field of culture sciences. 'It is a matter here of constructing relationships which our imagination accepts as plausibly motivated and hence as "objectively possible" and which appear as adequate from the nomological standpoint' (Weber 1949: 92).

A great confusion also comes from identifying the dominant ideas of an epoch, that is of the ideals and values that have animated a great part of the population and the ideas that have the function of an ideal type. This confusion comes from the fact that sometimes the ideal type achieved through abstraction from the social phenomena characteristic to an epoch represents, by chance, for many contemporaries of that epoch the ideal they strived to reach, even in a less clear, confused and instinctive form.

However, even these diffuse ideals cannot be clarified other than through abstract, ideal typical constructions. If, for instance, we would try to study medieval Christianity, we would 
have to face a chaos of different ideas and feelings, an enormous mass of events and actions of gestures and representations very different from one another. 'Medieval Christianity' is an ideal typical concept. As a matter of fact, all the statements having the essence of Christianity as objects are, in their essence, nothing else than ideal types, with an inevitably relative and problematic validity as long as they pretend to be the rendering of empirical reality. Nevertheless, ideal types possess an exceptional heuristic value since it is the only way we can measure, compare and clarify reality. Therefore they are absolutely necessary for research. 'There is still another even more complicated significance implicit in such ideal-typical presentations. They regularly seek to be, or are unconsciously, ideal-types not only in the logical sense but also in the practical sense, i.e. they are model types which - in our illustration - contain what, from the point of view of the expositor, should be and what to him is "essential" in Christianity because it is enduringly valuable. If this is consciously or - as it is more frequently - unconsciously the case, they contain ideals to which the expositor evaluatively relates Christianity' (Weber 1949: 97-98).

All these may be very different from those of the contemporaries of the studied epoch; for instance, from those of the first Christians. It is obvious that within this meaning, the ideas are not only helpful, purely logical means, but also ideals in the light of which reality is appreciated and interpreted. As a result, in such a case, we are not just dealing with a theoretical process of relating the empirical to certain values, but also with value judgments embedded in the concept of 'Christianity' or with interpretations of Christianity in the light of what Max Weber calls axiological interests. If the ideal type is presented as having empiric validity, it leaves the sphere of science. The ideational figment presented this way represents the illustration of a personal belief, not an ideal typical construction. The imagination that the ideal type creator absolutely needs must not be mistaken for the fantasy of a novelist (Freund 1994: 487).

In the lectures of researchers in the culture sciences, in history, for instance, two levels are usually mistaken: that of a scientific analysis of phenomena with that of their own interpretations and appreciations. On the one side, Max Weber states, the researcher cannot refrain from formulating value judgments and, on the other hand, he does everything not to take responsibility for these judgments. We have to oppose the fundamental obligation of scientific self-control to this temptation (Weber 1949: 98).

An ideal type, such as it is devised by Max Weber, represents a control authority against any interpretation and assessment of reality, completely neutral from an axiological point of view. Thus, it becomes, Gadamer states, an extremely important 'hermeneutical and methodological concept' (Gadamer 2004: 509) not only for comprehensive sociology, but also, in our opinion, for all culture sciences because they all are 'interpretive'. In Max Weber's conception, sociology is comprehensive 'inasmuch as its object is the common meaning of social action. It is true that the meaning that is 'subjectively intended' in the area of social and historical life cannot be only that which is actually meant by the individual actors' (Gadamer 2004: 509). The ideal type as neutral authority from an axiological point of view is an instrument for ordering chaos from interpretations of phenomena that are attributed various values and meanings. 'The whole edifice rests on this basis, which Max Weber calls "rationalistic", an edifice which is, in its conception, "value free" and neutral, a monumental bastion of "objective" science, which defends its methodological clarity by a classificatory system and, in those parts that he completed, leads to a great systematic survey of the world of historical experience (Erfahrung)' (Gadamer 2004: 509).

It has to be perfect from a logical-epistemological point of view and it is absolutely necessary that it should not be mixed with axiological considerations. Karl Marx represents the greatest ideal-types constructor in history according to Max Weber. An imposing conceptual construction 
as the one in Capital is ideal typical to the extent that it is typical from a theoretical point of view. The heuristic importance of its notions is obvious as a means of ordering and comparing reality, but to consider that reality works as in Karl Marx's theory was, and still is, a serious error.

The ideal type, as it was devised by Max Weber in his methodological essays, is the central concept of the process of value interpretation of a certain civilisation. In its role of a hermeneutical instrument, the ideal type is not the product of the researcher in the field of human sciences (Geisteswissenschaften), but of someone who prepares the ground for such a research. The ideal type creator is primarily a value theorist, such as Karl Marx was. In his book, Capital, he pointed out the spirit of capitalism better than any other scientist of his time if we are to use this phrase from the title of a famous Max Weber's work, which he characterized like this, 'As soon as we try to give it some kind of "definition", certain difficulties related to the essence of the research purpose appear. If generally speaking we may find an object for which using a characterization has a certain meaning, it cannot be anything but a "historic individual", that is a complex of connections from the historic reality by which we reunite them conceptually in a whole from the point of view of their cultural significance' (Weber 2017: 21). The ideal type of capitalism, like any ideal type, is first of all a hermeneutic means of understanding an individual historical phenomenon regarded as a whole or as what Max Weber calls 'historisches Individuum', assuming the phrase from neo-Kantian philosophers of values. In other words, the ideal capitalism described by Karl Marx in the Capital is the premise for understanding any concrete form of capitalism, irrespective of the time and place it manifests itself. Generalising, one can say that any less 'typical' historic phenomenon may be understood only if we relate it to its ideal type. 'An "ideal type" in our sense, to repeat once more, has no connection at all with value-judgments, and it has nothing to do with any type of perfection other than a purely logical one. There are ideal types of brothels as well as of religions; there are also ideal types of those kinds of brothels which are technically "expedient" from the point of view of police ethics as well as those of which the exact opposite is the case' (Weber 1949: 98-99).

It does not matter how honest a researcher from the field of human sciences may be, he has the tendency, Max Weber says, to idealize the object of his research in a moral sense, something that affects the objectivity of scientific knowledge. The axiological interpretation has precisely the role of clarifying what is unconscious or semiconscious in such a tendency. The old principle of understanding an author better than he understood himself is 'the necessary consequence of the doctrine of unconscious creation' (Dilthey 1900: 202), such as Wilhelm Dilthey very well described it, becomes central to the hermeneutics of values.

Axiological interpretation, Max Weber states, must not be mistaken for assessment. It consists of developing several possible evaluative points of view for a given phenomenon. Therefore, it is about placing a series of different perspectives on the same historic or cultural phenomenon in parallel and showing the respective point of view of a researcher or an author. Such preliminary research from the field of culture sciences highlight what Max Weber calls axiological interests (Wertinteresse) (Weber 1992: 277). Finding these is one of the major goals of axiological interpretation.

\section{THE BIRTH OF THE HERMENEUTICS OF VALUES}

Another important element of the process of axiological interpretation is represented by establishing the reference to values, a phrase that Max Weber took from Heinrich Rickert's philosophy of value. This Wertbeziehung must not be mistaken for a value judgment. Max Weber was often challenged that such a concept was ambiguous and 'the ideas coming out of his pages 
are not very clear' (Veyene 1999: 71). It is true that he never points out any particular values in such a context, but the value in general; however, he does not even need to do so since his intention was to emphasize a methodological principle of utmost generality in the field of culture sciences. He means to say, for instance, that all historians, from any place and any time, were not concerned and would never be concerned with the entire history of their civilisation of the entire human race, but made a selection of the phenomena that became 'historical' by means of certain values. 'Value-orientation determines the questions we put to reality. If a historian were asked why, for example, he was interested in the French Revolution or in Fichte's philosophy, or a sociologist why he studied social relationships in a workers' settlement or the living conditions of university students, either would doubtless reply that the subjects were interesting ones, or again, that they were important. Weber was not content with such vague answers, and put yet another pertinent question: why is a particular question important, and in relation to what? The reply to both parts of this question involves reference to values' (Freund 1998: 52).

Any empirical research in the field of cultural sciences begins with determining the object of the research by means of a selection of the empiric material whose condition is precisely Wertbeziehung. This represents 'the philosophical interpretation of that specifically scientific "interest" which determines the selection of a given subject-matter and the problems of an empirical analysis' (Weber 1949: 22). From Max Weber's point of view, the goal of the axiological interpretation is, among others, establishing the interest a researcher has when he assigns cultural significance to an empirical reality. "The concept of culture is a value-concept. Empirical reality becomes "culture" to us because and insofar as we relate it to value ideas... Only a small portion of existing concrete reality is coloured by our value-conditioned interest and it alone is significant to us. It is significant because it reveals relationships which are important to us due to their connection with our values. Only because and to the extent that this is the case is it worthwhile for us to know it in its individual features' (Weber 1949: 77). This interest, present even in the most objective research in the field of the culture sciences, is dynamic. It changes from one epoch to another, so that it may be rediscovered only by means of a very precise axiological interpretation. The hermeneutical problem raised by such axiological interests (Wertinteresse), which Max Weber is often referring to in his methodological essays, covers the following aspects. Firstly, discovering the interest that was at the basis of assigning a cultural significance to a certain empiric reality is also made by means of other Wertinteresse, such as the case of history, which is written based on the axiological interests of the present time, as Max Weber observes. Secondly, the axiological interpretation oriented towards unveiling the interest of a certain researcher or an author raises a big question mark with respect to the honesty of the interpreter. In this field, hermeneutic equity, theorized by Friedrich Meier (Meier 1965: 20), becomes a major object of reflection.

Thirdly, the axiological interests of the society a certain researcher is a part of are almost impossible to observe by the researcher himself. For instance, 'in ever so many cases, the adduced evaluations of daily life have formed the object and paved the way for historical research - this occurs even in the beginnings of all historical writing in political communities, especially in the historian's own state. The historian might thus come to believe when he confronts these fixed and firm "objects" which apparently - but only apparently and only in the range of familiar, routine use - do not require any special value-interpretation' (Weber 1949: 160-161). Actually, Max Weber continues, the historian should first interpret the reality that would become the object of his research as if he were interpreting Goethe's Faust. In other words, before someone analyses Faust's esthetical value, somebody else, by means of an axiological interpretation, has already established that this work is significant from a cultural point of view. 
Fourthly, Wertinterpretation is also a means of emphasizing a certain Weltanschauung of the author or of his epoch, taking into consideration that a Weltanschauung is always essentially a conception of values or a Weltanschauung (Weber 1949: 77). Since it clarifies his own Weltanschauung, the axiological interpretation helps the one resorting to it in making important decisions that imply choosing one value at the expense of others.

In the case of social sciences, Max Weber says, we deal with the intervention of spiritual phenomena that must be understood by reliving, with the meaning assigned to this phrase by Wilhelm Dilthey. The axiological interpretation is the one who facilitates the appropriate reliving of a certain foreign spiritual content, laid out in texts, in historic relics or in various works of art. The interpreter of values is neither a theorist, because values as well as feelings belong to the emotional side of the human spirit and not the rational, nor an empirical researcher, because the values cannot be established by induction starting from empirical data. Value interpretation requires intuition and artistic genius. Valuable ideas (Wertideen) through which empirical reality is ordered cannot be discovered other than intuitively and cannot be shown to the public other than in an artistic manner. Hence, the frailty of the human sciences (Geisteswissenschaften) is compared to the nature sciences. Only a gifted researcher endowed with artistic genius, such as the historian Ranke, cited by Max Weber to illustrate this idea, may discover the cultural significance that personalities from other epochs and civilisations attributed to things.

'The feeling' as a moment of understanding the values is a concept Max Weber took over from Wilhelm Dilthey. In Genesis of Hermeneutics, he specifies that may become objective to some extent only when the interpreter returns to the object of the interpretation by means of a new 'feeling.' 'In this respect, there is an art of interpretation whose subjects are sculptures and paintings' (Dilthey 1900: 189). All human creations, not only those in a written form, are open to interpretation and thus become an object of the hermeneutics of values. They are capable of determining certain 'feelings', which means they are carriers of certain spiritual values that may be disclosed by means of a special interpretation. Just like in the case of a text, understanding of the parts starting from a whole and of the whole starting from its parts represents one of the fundamental hermeneutical rules: axiological interpretation is based on the hermeneutical circle. Particular values, laid out in works of art and various creations, must be understood, on the one hand, starting from the system of values they emerged from and, on the other hand, the general system of values must be understood starting from the various particular forms of value objectivation. Therefore, the hermeneutical circle expresses in this field, as well, the limitation inherent to any process of axiological interpretation. The interpretation of values is always relative, and 'feeling' them is debatable at any moment, even in the technical sense Erlebnis has in Dilthey's famous book Das Erlebnis und die Dichtung. Hans Georg Gadamer states, 'The classical discipline concerned with the art of understanding texts is hermeneutics. If my argument is correct, however, the real problem of hermeneutics is quite different from what one might expect. It points in the same direction in which my criticism of aesthetic consciousness has moved the problem of aesthetics. In fact, hermeneutics would then have to be understood in so comprehensive a sense as to embrace the whole sphere of art and its complex of questions' (Gadamer 2004: 157). This thesis has to be extended through to the whole field of human creations. However, we deal with values, interpreting is not only possible, but also necessary. The object of research in cultural sciences emerges only in the act of axiological interpretation. This act is not a reproduction, but a production or, to be more specific, a delineation of the object of research, starting from the feelings of a certain researcher towards certain values. 
The hermeneutics of values is a discipline, in our opinion, merely sketched in the literature so far. The critique of the historical reason undertaken by Dilthey, together with Manfred Riedel's Hermeneutik der Wertung (Riedel 1979: 101-107) to which a multitude of reflections on value interpreting from various authors is added, represents, without any doubt, a large basis for the edification of the hermeneutics of values. The value context in which a certain work or an event will become 'historic' is born, must be seen as a semantic context that tremendously transcends the capacity of feeling of the individual, in the sense attributed by Dilthey to this phrase. Precisely because such a value context is similar to a text difficult to decipher, a hermeneutics of values would be necessary, like an Ariadne's thread through a labyrinth of cultural meanings.

\section{CONCLUSIONS}

Despite the fact that axiological interpretation is a concept that appears in Max Weber for the first time, but which has not entered among the fundamental concepts of the human sciences (Geisteswissenschaften) until today, the phenomenon as such has existed throughout European civilisation. Nevertheless, a hermeneutics of values did not exist and still does not exist to this day. As we know, theological and legal hermeneutics were set up as early as the Greco-Roman Antiquity, to which others were added during Medieval and Modern history. Starting from these, a general hermeneutics was devised, especially through Schleiermacher's contribution. Today, a reverse phenomenon should take place: starting from general hermeneutics, which has considerably improved since Schleiermacher, new special hermeneutics should be devised. A hermeneutics of values would be, in this respect, more than necessary.

\section{ACKNOWLEDGEMENTS}

This work was supported by a grant from the Romanian National Authority for Scientific Research and Innovation, CCCDI - UEFISCDI, Project Number 17/2016, Heritage Plus - HeAT, within PNCDI III.

Received 2 May 2018

Accepted 15 June 2018

\section{References}

1. Dilthey, W. 1900. Die Entstehung der Hermeneutik. Tübingen: J. C. B. Mohr (Paul Siebeck) Verlag.

2. Freund, J. 1994. "Die Rolle der Phantasie in Webers Wissenschaftslehre. Bemerkungen zu seiner Theorie der objektiven Möglichkeit und der adäquaten Verursachung", in Max Webers Wissenschaftslehre. Interpretation und Kritik. Frankfurt am Main: Suhrkamp Verlag.

3. Freund, J. 1998. The Sociology of Max Weber. London and New York: Routledge.

4. Gadamer, H. G. 2004. Truth and Method. London and New York: Continuum Publishing Group.

5. Hessen, J. 1937. Wertphilosophie. Padeborn/Wien/Zürich: Verlag F. Schöningh.

6. Meier, G. Fr. 1965. Versuch einer allgemeinen Auslegungskunst. Düsseldorf: Stern-Verlag.

7. Nietzsche, Fr. 1999. The Will to Power. Bucureşti: Editura Aion.

8. Riedel, M. 1979. Norm und Werturteil. Grundprobleme der Ethik. Stuttgart: Reclam Verlag.

9. Steinvorth, U. 1994. "Webers Freiheit von der Wertfreiheit", in Max Webers Wissenschaftslehre. Interpretation und Kritik. Frankfurt am Main: Suhrkamp Verlag.

10. Veyene, P. 1999. Cum se scrie istoria. Bucureşti: Editura Meridiane.

11. Weber, M. 1992. "Der Sinn der "Wertfreiheit" der soziologischen und ökonomischen Wissenschaften", in Soziologie. Universalgeschichtliche Analysen. Politik. Stuttgart: Kröner Verlag.

12. Weber, M. 1985. Gesammelte Aufsätze zur Wissenschaftslehre. Tübingen: J. C. B. Mohr (Paul Siebeck) Verlag.

13. Weber, M. 1949. On the Methodology of the Social Sciences. Illinois: The Free Press.

14. Weber, M. 2017. Die protestantische Ethik und der "Geist" des Kapitalismus. Stuttgart: Reclam Verlag. 
NICOLAE RÂMBU

\section{Maxo Weberio minties aksiologinė interpretacija: naujas požiūris ị svarbią hermeneutinę sąvoką}

Santrauka

Straipsnyje ginama tezè, kad Maxo Weberio minties aksiologinè interpretacija (Wertinterpretation) galètų vaidinti išskirtinị vaidmenị. Tai svarbu socialinių mokslų metodologijos ir filosofinès hermeneutikos sričiai. Iki šiol tema ir pati aksiologinès interpretacijos sąvoka buvo pernelyg mažai nagrinejjama hermeneutikos istorijoje. Straipsnyje aptariama, ką reiškia aksiologinès interpretacijos sąvoka, kokia jos išraiška, kuo ypatingos sąsajos su tikrove ir jos vertemis civilizacijos istorijoje.

Raktažodžiai: vertybių hermeneutika, aksiologiniai interesai, nuoroda ị vertybes 